\title{
INVESTIGATION OF SILICON AND MANGANESE SOLUBILITY IN CEMENTITE OF IRON-BASED ALLOYS
}

\author{
(D)Natalia Filonenko",2*, (D)Alexander Babachenko², (DGanna Kononenko² \\ ${ }^{1}$ State Institution "Dnipropetrovsk Medical Academy of Health Ministry of Ukraine" \\ 9, Vernadsky Str., Dnipro,49044, Ukraine \\ ${ }^{2}$ Z.I. Nekrasov Iron and Steel Institute of National Academy of Sciences of Ukraine \\ 1, Ak. Starodubova K.F. sq., Dnipro, 49107, Ukraine \\ *E-mail:natph2016@gmail.com \\ Received March 11, 2019; revised March 26, 2019; accepted April 17, 2019
}

\begin{abstract}
In the paper we obtained the expression of cementite free energy and determined the solubility of manganese and silicon in $\mathrm{Fe}_{3} \mathrm{C}$ cementite depending on the temperature. Investigation was carried out for alloys with carbon content of $0.55-0.60 \%$ (wt.), silicon content of $0.95-1.0 \%$ (wt.), manganese content of 0.8-0.9\% (wt.), the rest was iron. The smelting of Fe-Mn-Si-C system alloys was carried out in the alundum crucible furnace in argon atmosphere. The cooling rate of alloys after casting was $10 \mathrm{~K} / \mathrm{s}$. Microstructure analysis along with X-ray diffraction analysis was used to determine the structural state of the alloys. In addition, the physical characteristics of the alloys studied in this paper were determined, such as alloy chemical dependence of ultimate strength, extension and contraction ratio, impact toughness and hardness. The results obtained in this paper showed that the iron-based alloy with the content of carbon of $0.57 \%$ (wt.), silicon of $0.97 \%$ (wt.) and manganese of $0.85 \%$ (wt.)) had the superior microstructure and physical properties. The microstructure of alloys studied in the paper is represented by pearlite, which makes up to $95 \%$ of the volume. In the alloys we revealed the highly dispersed inclusions of $\mathrm{Fe}_{2.7} \mathrm{Mn}_{0.3} \mathrm{C}, \mathrm{Fe}_{0.25} \mathrm{Mn}_{1.4} \mathrm{C}_{0.6}$ and $\mathrm{Fe}_{9} \mathrm{SiC}_{0.4}$ carbides, whose volume ratio was up to $1.5 \%$, the rest was ferrite. As it is known, the structural constituent of pearlite is cementite. The cementite has a significant effect on the physical properties of alloys. Application of quasi-chemical method enables to calculate the free energy of silicon and manganese doped with cementite and to determine the temperature dependence of silicon and manganese content in cementite. It is ascertained that there is a slight increase of carbon content in cementite (up to $28.79 \%$ (atoms). Manganese can replace up to $12 \%$ of iron atoms, and silicon can replace up to $4.5 \%$ of iron atoms, depending on temperature. The calculated data obtained in this paper are in good agreement with those found experimentally by other authors.
\end{abstract}

KEYWORDS: Fe-Mn-Si-C alloys, cementite, free energy of cementite, solubility of manganese and silicon in cementite

The up-to-date working conditions of railway wheels require the development of new steels, whose chemical composition, along with the heat treatment, provide increased strength and hardness of metal for wheels with a view to increase their operational properties (wear resistance, resistance to the formation of shelled tread, maximum load on the axle). At the formation of the complex of mechanical properties of railway wheels an important role is played by the morphology and chemical composition of $\mathrm{Fe}_{3} \mathrm{C}$ cementite, which is formed in steel during crystallization and thermal treatment of these products. The formation of $\mathrm{Fe}_{3} \mathrm{C}$ cementite is known to occur in iron steels and alloys with carbon content of more than $0.01 \%$ (wt.) [1]. Cementite has a complex crystal lattice and contains $6.67 \%$ (wt.) of carbon. Doping of $\mathrm{Fe}_{3} \mathrm{C}$ cementite by metal atoms affects the physical properties of steels and alloys. In the process of doping steels by manganese (regardless of its amount), by chromium (up to 2\%), or by stronger carbide-forming elements (tungsten, molybdenum), they dissolve in cementite, partially replacing the atoms of iron in its crystalline lattice. Here, some doped cementite, for example $(\mathrm{Fe}, \mathrm{Cr})_{3} \mathrm{C}$ or $(\mathrm{Fe}, \mathrm{Mn})_{3} \mathrm{C}$, is formed, which differs as to its physical properties from the ordinary non-doped cementite $\mathrm{Fe}_{3} \mathrm{C}$. Nickel and silicon are referred to graphite-forming elements that affect decomposition of $\mathrm{Fe}_{3} \mathrm{C}$ carbide resulting in the release of free-state carbon, i.e. graphite [1].

The most promising for the railway wheels is doping of steel with such inexpensive basic chemical elements as manganese and silicon. At doping of this kind, the formation of phases $\left(\mathrm{Fe}_{11} \mathrm{Si}_{1}\right) \mathrm{C}_{4}$ and $\left(\mathrm{Fe}_{11} \mathrm{Mn}\right) \mathrm{C}_{4}, \mathrm{Fe}_{2.7} \mathrm{Mn}_{0.3} \mathrm{C}$ [2-4], as well as of cementite $\mathrm{Fe}_{3} \mathrm{C}$ doped with manganese and silicon is possible.

The object of this work was to determine the phase composition of the iron-based alloys doped with manganese and silicon, as well as solubility of these elements in cementites depending on the temperature.

\section{MATERIALS AND RESEARCH TECHNIQUES}

The research was carried out on the samples of steels with content of carbon of $0.55-0.60 \%$ (wt.), silicon $0,95-1,0 \%$ (wt.), manganese $0,8-0,9 \%$ (wt.), the rest was iron. Melting of the experimental steels and manufacture of the railway wheels from them was carried out under industrial conditions at the enterprises of "INTERPIPE-Ukraine" Company. Fe-Mn-Si-C alloys were molten in the alundum crucible furnace in the argon atmosphere. The rate of cooling of castings was $10 \mathrm{~K} / \mathrm{s}$. The samples after moulding had a cylindrical shape and the following dimensions: diameter $15 \mathrm{~mm}$ and height $-30 \mathrm{~mm}$. To determine the chemical composition of the alloy the chemical and spectral analysis was used [5]. The phase composition of the alloys was determined using an optical microscope "Neofot-21". The main results of the X-ray micro-spectral analysis were obtained using an electron microscope JSM-6490 with scanner ASID4D and a programmable energy-dispersive X-ray microanalyser "LinkSystems 860". The research of mechanical characteristics was performed on the device of SMC-2 model. The wear resistance tests were performed at the load of (C) Natalia Filonenko, Alexander Babachenko, Ganna Kononenko, 2019 
$700 \mathrm{~N}$, the slip factor made $10 \%$ under conditions of dry friction. The rate of the lower spindle rotation was 300 turns per minute. The X-ray diffraction analysis was performed on the DRON-3 diffractometer in monochromatic Fe- $\mathrm{K}_{\alpha}$ radiation. The theoretical calculation of the phases diffraction patterns was performed utilizing the program "CaRIne v. 3.1".

\section{RESULTS AND DISCUSSION}

The microstructure of the alloy containing carbon $(0.57 \%$ (wt.)), silicon $(0.97 \%$ (wt.)) and manganese $(0.85 \%$ (wt.)) in the molten state is represented by ferrite and grains of pearlite (Fig. 1a,b).

Pearlite in the alloy had dispersion morphology (Fig. 1c). High-dispersion inclusions with a bulk fraction of up to $1.5 \%$ were found in the alloy structure. As it is known, at doping the iron alloys with manganese and silicon, any pure carbides of manganese and silicon do not exist, but there are complex carbides [6]. In this alloy the carbides $\mathrm{Fe}_{2.7} \mathrm{Mn}_{0.3} \mathrm{C}, \mathrm{Fe}_{0.25} \mathrm{Mn}_{1.4} \mathrm{C}_{0.6}$ and $\mathrm{Fe}_{9} \mathrm{SiC}_{0.4}$ were found (Fig. 1b). The results of the micro-spectral analysis showed that the manganese content in the pearlite of the alloy made $0.75 \%$ (wt.) and that of silicon - $0.65 \%$ (wt.) (Fig. 1d).

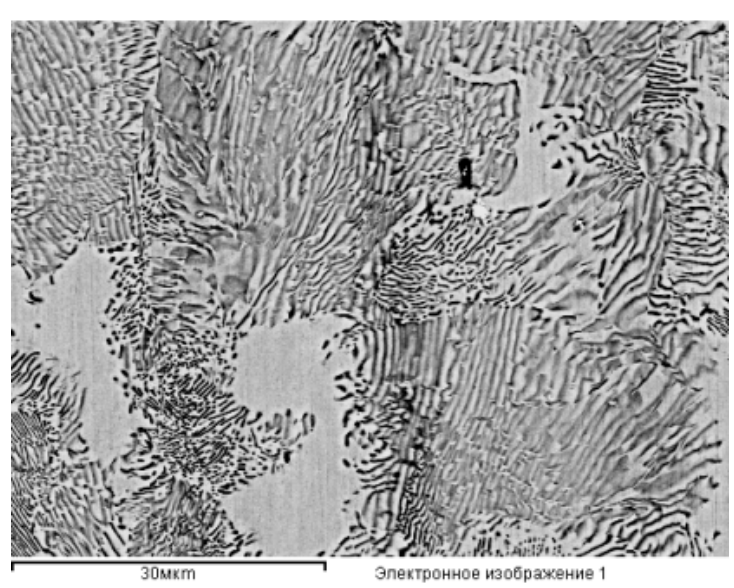

a

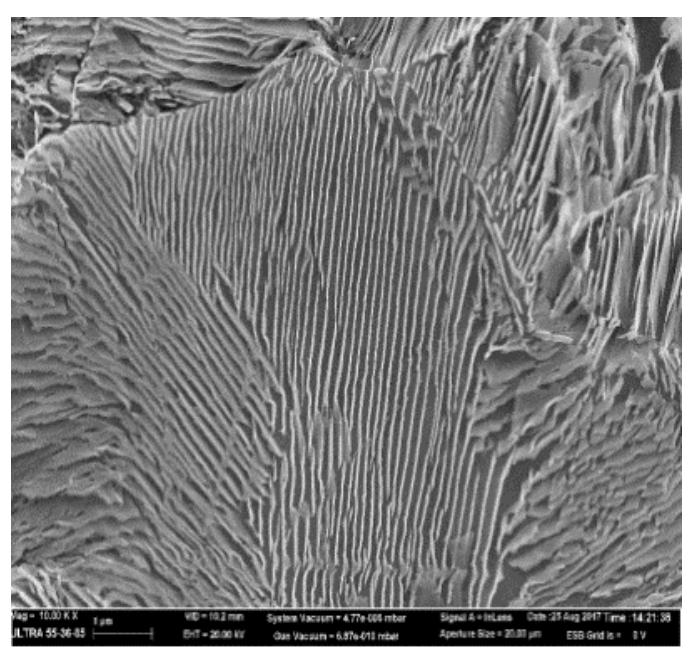

c

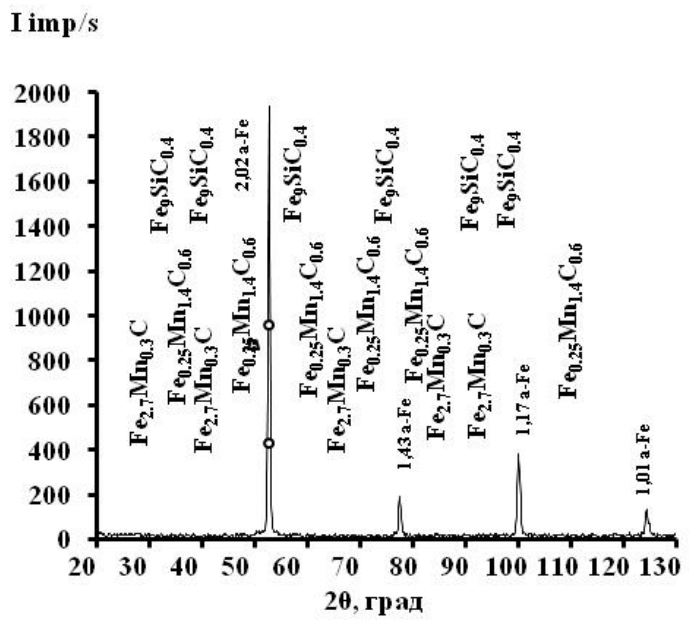

b

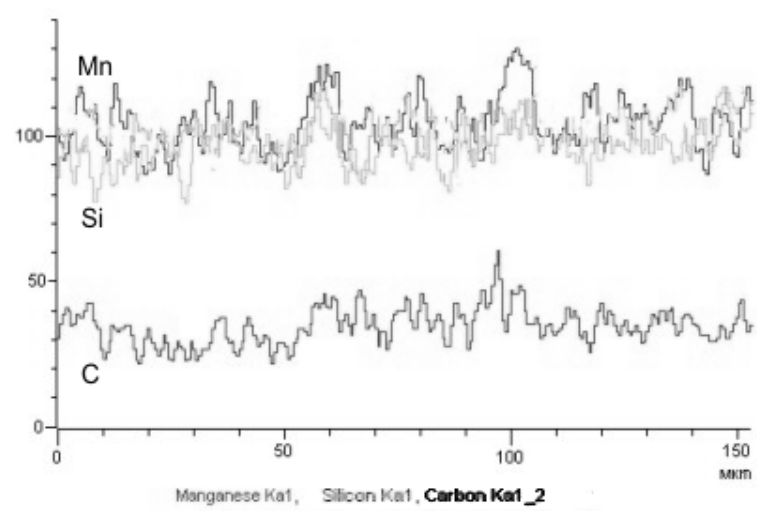

d

Fig. 1. Iron-based alloy containing carbon $(0.57 \%$ (wt.)), silicon ( $0.97 \%$ (wt.)) and manganese $(0.85 \%$ (wt.)) in the molten state: a) alloy microstructure, b) alloy diffractogram c) pearlite microstructure, d) spectrogram

In the alloy containing carbon $(0.58 \%$ (wt.)), silicon $(0.40 \%$ (wt.)) and manganese $(0.70 \%$ (wt.)) the microstructure was heterogeneous, that is, pearlite had both dispersed and highly dispersed structure (Fig. 2a). With content of carbon of $0.65 \%$ (wt.), silicon of $0.6 \%$ (wt.) and manganese of $0.75 \%(\mathrm{wt}$ ), the microstructure of the alloy is represented by pearlite having a non-uniform morphology, while manganese and silicon segregation was observed in the alloy microstructure along the boundaries of pearlite grains (Fig. 2b).

The alloys under study have practical application in the railway transport, so special attention in this work is paid to their physical properties.

As Table 1 shows, the characteristics of strength and hardness for all the alloys are high, and for the alloy containing carbon $-0.57 \%$ (wt.), silicon $-0.97 \%$ (wt.) and manganese $-0.95 \%$ (wt.), plasticity and fracture toughness are higher as compared to those for the other alloys that are used in the manufacture of railway wheels. 


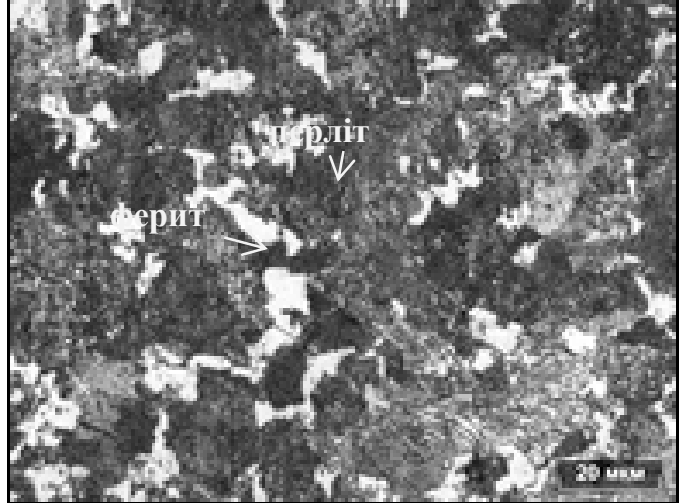

a

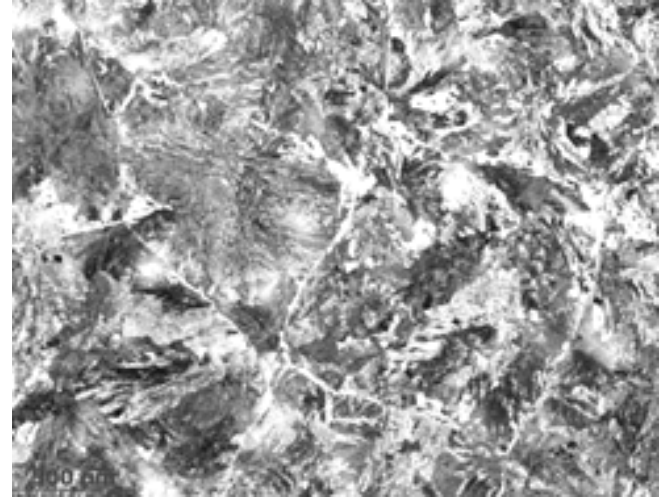

b

Fig. 2. The microstructure of the alloy containing: a) carbon $-0.58 \%$ (wt.), silicon $-0.40 \%$ (wt.) and manganese $-0.70 \%$ (wt.); b) carbon $-0.65 \%$ (wt.), silicon $-0.6 \%$ (wt.) and manganese $-0.75 \%$ (wt.), $\times 500$

Table 1.

Dependence of the strength limit, extension and contraction ratio, impact toughness and hardness on the chemical composition

\begin{tabular}{|l|l|l|l|l|l|}
\hline $\begin{array}{c}\text { Content of chemical elements in } \\
\text { alloys, \% (wt.) }\end{array}$ & $\begin{array}{c}\text { The strength } \\
\text { limit, } \\
\sigma_{\mathrm{v}}, \mathrm{N} / \mathrm{mm}^{2}\end{array}$ & $\begin{array}{c}\text { Relative } \\
\text { extension } \mathrm{n}, \delta, \%\end{array}$ & $\begin{array}{c}\text { Relative } \\
\text { contraction } \psi, \%\end{array}$ & $\begin{array}{c}\text { Impact toughness, } \\
\mathrm{KCU}_{\text {obed, }} / \mathrm{cm}^{2}\end{array}$ & $\begin{array}{c}\text { Hardness, } \\
\mathrm{HB}\end{array}$ \\
\hline $\mathrm{C}=0.57 ; \mathrm{Si}=0.97 ; \mathrm{Mn}=0.85$ & 1160 & 12.5 & 31 & 27 & 326 \\
\hline $\mathrm{C}=0.65 ; \mathrm{Si}=0.6 ; \mathrm{Mn}=0.75$ & $\geq 1020$ & 9 & 16 & 18 & $\geq 320$ \\
\hline $\mathrm{C}=0.58 ; \mathrm{Si}=0.40 ; \mathrm{Mn}=0.7$ & 960 & 8 & 14 & 20 & $\geq 255$ \\
\hline
\end{tabular}

The microstructure of alloys studied in this paper was represented by pearlite, whose bulk fraction was up to $95 \%$. Cementite is the structural component of pearlite, which affects the alloys mechanical properties.

Cementite has a complex structure [4]. The authors of the work gave a definition of the cementite structure and pointed to the peculiarity of the structure of cementite, which consists in the fact that the atoms of iron and carbon form Z-shape chains [7].

Each elementary cell contains 12 iron atoms, 4 of which are located in the FeI (4c) position and 8 - in the FeII (8d) position. In the crystal lattice of carbide $\mathrm{Fe}_{3} \mathrm{C}$ the carbon atoms are located in the middle of the prisms.

By the results presented in the paper the crystallographic program "CaRIne v.3.1" was utilized to form the carbide crystal structure.

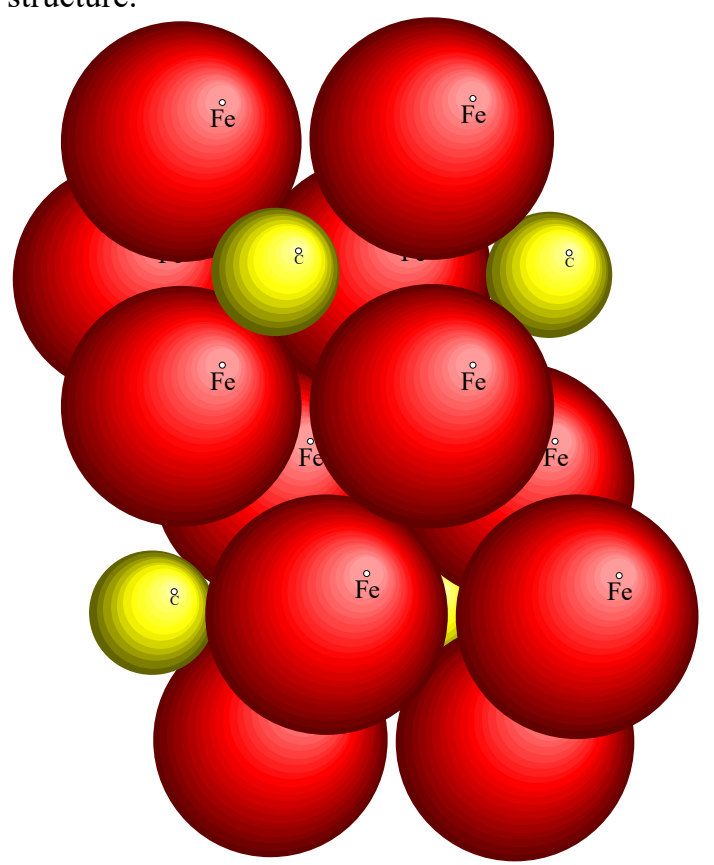

Fig. 3. The structure of $\mathrm{Fe}_{3} \mathrm{C}$ carbide

According to the results of the crystal lattice formation the distance between the iron and carbon atoms in the trigonal prism is $1.906 \AA, 2.041 \AA$, $2.064 \AA$ and $2.11 \AA$, what corresponds to the results given in [3]. The distance between the nearest one to another carbon atoms is $3.12 \AA$.

To obtain the calculation results of the limit of carbon atoms solubility in the carbide lattice a quasi-chemical method was used [8]. The carbon atoms in the carbide can be conventionally located in two sublattices. The first sublattice (location) consists of carbon atoms containing six nearest iron atoms, two of which belong to the position of iron atoms FeII, and are located at the distance of $2.11 \AA$, and four - to the position FeI, two of them are located at the distance of $2.04 \AA$, and two - at the distance of $1.91 \AA$. The other sublattice consists of two closest carbon atoms, interacting with each other, which are located at the distance of $3.12 \AA$ (Fig. 3).

The interaction of the $\mathrm{Fe}-\mathrm{C}, \mathrm{M}-\mathrm{C}$, and $\mathrm{C}-\mathrm{C}$ atoms can be considered as follows: the interaction energy of the pairs of atoms: for the first sublattice for the iron atoms position FeII $-v_{\text {FeIIC }}, v_{\text {MIIC }}$, for 
the position FeI $-v_{M_{1} \mathrm{C}}, v_{\mathrm{Fel}_{1} \mathrm{C}}$, and for two atoms of iron and manganese located at the distance of 1, $91 \AA$ from the carbon atoms $-v_{\mathrm{MI}_{2} \mathrm{C}}, v_{\mathrm{FeI}_{2} \mathrm{C}}$. For two carbon atoms, located at the distance of $3.12 \AA-v_{\mathrm{CC}}$. For the numerical values of the energy of interaction of the pairs of atoms the results given in [9] were used.

The free energy of carbide can be determined by the formula: $F=E-k T \ln W$, where $E$ is the internal energy of $\mathrm{Fe}_{3} \mathrm{C}$ phase, $W$ is the thermodynamic probability of the atoms location in the sites of the carbide crystal lattice, $k=1.38 \cdot 10^{-23}, \mathrm{~J} / \mathrm{K}$ is Boltzmann constant, $T$ is absolute temperature.

Thus, the free energy of carbide is determined as follows:

$$
\begin{aligned}
& F=-\sum_{i=1}^{2}\left(N_{F e I I i} N_{C i} v_{F e I I C}+N_{M I I i} N_{C i} v_{M I I C}\right)-\sum_{i=1}^{2}\left(N_{F e I_{1} i} N_{C i} v_{F e_{1} I C}+N_{M I_{1} i} N_{C} v_{M I_{1} C}\right)- \\
& -\sum_{i=1}^{2}\left(N_{\mathrm{FeI}_{2} i} N_{\mathrm{C}} v_{\mathrm{FeI}_{2} \mathrm{C}}+N_{\mathrm{MI}_{2} i} N_{C} v_{\mathrm{MI}_{2} \mathrm{C}}\right)-\sum_{i=1}^{2} N_{C i} N_{\mathrm{Ci}} v_{C \mathrm{C}}- \\
& -k T\left(\left(N_{\text {FeII }}+N_{\text {MII }}\right) \ln \left(\left(N_{F e I I}+N_{\text {MII }}\right)-1\right)-N_{\text {FeII }} \ln \left(N_{F e I I}-1\right)-N_{\text {MII }} \ln \left(N_{\text {MII }}-1\right)+\right. \\
& +\left(N_{F e I_{1}}+N_{M I_{1}}\right) \ln \left(\left(N_{F e I_{1}}+N_{M I_{1}}\right)-1\right)-N_{F I_{1}} \ln \left(N_{F_{F I}}-1\right)-N_{M I_{1}} \ln \left(N_{M I_{1}}-1\right)+ \\
& +\left(N_{\mathrm{FeI}_{2}}+N_{\mathrm{MI}_{2}}\right) \ln \left(\left(N_{\mathrm{FeI}_{2}}+N_{\mathrm{MI}_{2}}\right)-1\right)-N_{\mathrm{FeI}_{2}} \ln \left(N_{\mathrm{FeI}_{2}}-1\right)-N_{\mathrm{MI}_{2}} \ln \left(N_{\mathrm{MI}_{2}}-1\right)+ \\
& +\left(N-N_{M e}\right) \ln \left(\left(N-N_{M e}\right)-1\right)-N_{C} \ln \left(N_{C}-1\right) \text {, }
\end{aligned}
$$

where $N_{M e}=N_{F e I I}+N_{M I I}+N_{F_{e I}}+N_{M_{1}}+N_{F^{2} I_{2}}+N_{M I_{2}}, N_{C}$ is the number of carbon atoms, $N$ is the total number of sites in the lattice, respectively.

To calculate the solubility of carbon in cementite the solution of the system of equations should be found:

$$
\frac{\partial F}{\partial N_{F e I I}}=0, \frac{\partial F}{\partial N_{M I I}}=0, \frac{\partial F}{\partial N_{F e I_{1}}}=0, \frac{\partial F}{\partial N_{M I_{1}}}=0, \frac{\partial F}{\partial N_{F e I_{2}}}=0, \frac{\partial F}{\partial N_{M I_{2}}}=0 \text { та } \frac{\partial F}{\partial N_{C}}=0 .
$$

The resulting system of equations (2) is transcendental. Usually the solution of such equations can be obtained graphically or numerically. But in the framework of this problem it is expedient to consider an asymptotic solution of the equations. For this we present the logarithm included in each of the equations of the system (2) in the form of Taylor series (this is acceptable in case of its convergence):

$$
\begin{aligned}
& \frac{\partial F}{\partial_{\text {FeII }}}=-\sum_{i=1}^{2} N_{C i} v_{\text {FeIIC }}-k T\left(\frac{(-1)^{n-1}\left(N_{\text {FeII }}\right)^{n}}{n}+\sum_{n=1}^{\infty} \frac{(-1)^{n}\left(N_{\text {FeII }}\right)^{n+1}}{\left(N_{\text {MII }}\right)^{n+1}(n+1)}-\sum_{n=1}^{\infty} \frac{(-1)^{n-1}\left(N_{\text {FeII }}-1\right)^{n}}{n}=0\right. \\
& \frac{\partial F}{\partial_{M I I}}=-\sum_{i=1}^{2} N_{C i} v_{M I I C}-k T\left(\frac{(-1)^{n-1}\left(N_{M I I}\right)^{n}}{n}+\sum_{n=1}^{\infty} \frac{(-1)^{n}\left(N_{M I I}\right)^{n+1}}{N_{F e I I}^{n+1}(n+1)}-\sum_{n=1}^{\infty} \frac{(-1)^{n-1}\left(N_{M I I}-1\right)^{n}}{n}\right)=0 \\
& \frac{\partial F}{\partial N_{F e I_{1}}}=-\sum_{i=1}^{2} N_{C i} v_{F e l_{1} C}-k T\left(\frac{(-1)^{n-1}\left(N_{F_{e I_{1}}}\right)^{n}}{n}+\sum_{n=1}^{\infty} \frac{(-1)^{n}\left(N_{F e I_{1}}\right)^{n+1}}{\left(N_{M I_{1}}\right)^{n+1}(n+1)}-\sum_{n=1}^{\infty} \frac{(-1)^{n-1}\left(N_{F e I_{1}}-1\right)^{n}}{n}\right)=0 \\
& \frac{\partial F}{\partial N_{M I_{1}}}=-\sum_{i=1}^{2} N_{C i} v_{M I_{1} C}-k T\left(\frac{(-1)^{n-1}\left(N_{M I_{1}}\right)^{n}}{n}+\sum_{n=1}^{\infty} \frac{(-1)^{n}\left(N_{M I_{1}}\right)^{n+1}}{N_{F e I_{1}}^{n+1}(n+1)}-\sum_{n=1}^{\infty} \frac{(-1)^{n-1}\left(N_{M I_{1}}-1\right)^{n}}{n}\right)=0
\end{aligned}
$$

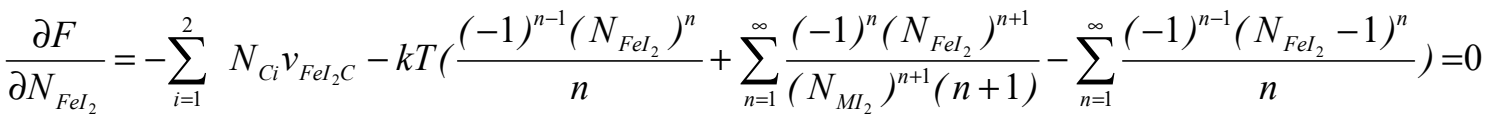

$$
\begin{aligned}
& \frac{\partial F}{\partial N_{M I_{2}}}=-\sum_{i=1}^{2} N_{C i} v_{M I_{2} C}-k T\left(\frac{(-1)^{n-1}\left(N_{M_{2}}\right)^{n}}{n}+\sum_{n=1}^{\infty} \frac{(-1)^{n} N_{M I_{2}}^{n+1}}{N_{F e I_{2}}^{n+1}(n+1)}-\sum_{n=1}^{\infty} \frac{(-1)^{n-1}\left(N_{M I_{2}}-1\right)^{n}}{n}\right)=0 \\
& \frac{\partial F}{\partial N_{C}}=-\sum_{i=1}^{2}\left(N_{F e I I i} v_{F e I I C}+N_{M I I i} v_{M I I C}\right)-\sum_{i=1}^{2}\left(N_{F e I_{1} i} v_{F e_{1} I C}+N_{M I_{1}} v_{M I_{1} C}\right)- \\
& -\sum_{i=1}^{2}\left(N_{\mathrm{Fe}_{2} i} v_{\mathrm{Fel}_{2} \mathrm{C}}+N_{\mathrm{ML}_{2} i} v_{\mathrm{Ml}_{2} \mathrm{C}}\right)-\sum_{i=1}^{2} 2 N_{\mathrm{Ci}} v_{C C}-k T\left(\sum_{n=1}^{\infty} \frac{(-1)^{n-1}\left(1-N_{C}\right)^{n}}{n}\right)=0
\end{aligned}
$$


To obtain an asymptotic estimate of system (3) solution it is sufficient to consider the first two terms of expansion in the logarithm expanding.

The results of the equations solution are shown in Fig. 3. With the growth of the temperature, the content of manganese and silicon in carbide $\mathrm{Fe}_{3} \mathrm{C}$ increases (Fig. 3).

The analysis of the results allowed determining the solubility of carbon, manganese and silicon in $\mathrm{Fe}_{3} \mathrm{C}$ carbide, i.e. it was found that there is a slight increase in carbon content in cementite (up to $28.79 \%$ (atoms)). Manganese can replace up to $12 \%$ of iron atoms, and silicon - up to $4.5 \%$ of iron atoms, subject to the temperature, what is in a good agreement with the experimental data.

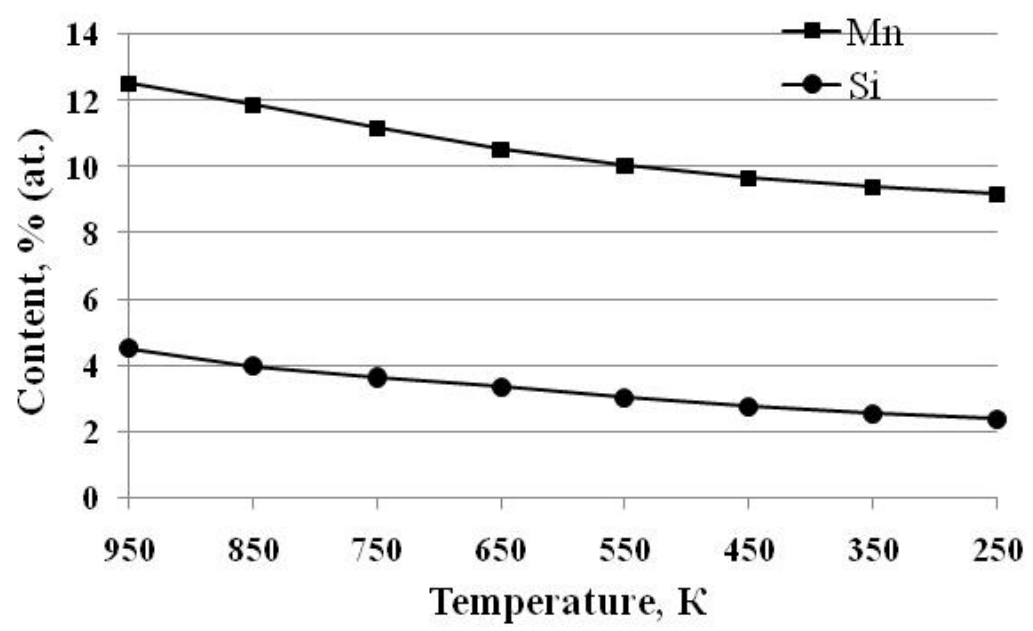

Fig. 3. Dependence of the content of manganese and silicon in $\mathrm{Fe}_{3} \mathrm{C}$ carbide on the temperature

\section{CONCLUSION}

The research was carried out on the alloys containing carbon $(0.55-0.60 \%$ (wt.), silicon (0.95-1.0\% (wt.), manganese $0.8-0.9 \%$ (wt.)), the rest was iron. To determine the structural state of the alloys the microstructure and Xray diffraction analyzes were performed. For the first time it was shown experimentally that the alloys of the Fe-Mn-Si$\mathrm{C}$ system containing carbon $(0.57 \%$ (wt.), silicon $(0.97 \%$ (wt.) $)$, manganese $(0.85 \%$ (wt.)) have better mechanical characteristics, namely, higher numerical value of strength and hardness, as well as of plasticity and fracture toughness, as compared to the alloys with a different content of carbon, manganese and silicon. Thus, the results obtained in this paper show that to improve the mechanical properties of the wheels to be used in the railway transport, the alloys containing carbon $(0.57 \%$ (wt.), silicon $(0.97 \%$ (wt. $))$, manganese $(0.85 \%$ (wt.)) can be used. The microstructure of this alloy contains up to $95 \%$ of the bulk fraction of pearlite, whose constituent is cementite. Therefore, to explain the good mechanical properties of the alloy the solubility limit of carbon, manganese and silicon in cementite $\mathrm{Fe}_{3} \mathrm{C}$ was determined using the quasi-chemical method. For the first time the expression for free energy of $\mathrm{Fe}_{3} \mathrm{C}$ cementite doped with manganese and silicon was obtained, and the limit of solubility of carbon, silicon and manganese in this phase was determined. It is ascertained that there is a slight increase in carbon content in cementite (up to 28.79\% (atoms)), the manganese can replace up to $12 \%$ of iron atoms, and silicon - up to $4.5 \%$ of iron atoms, subject to the temperature.

The work was carried out within the framework of the project "Resurs" KC063.18 "Expansion of chemical composition and technology solutions for manufacture of railway wheels for different application and their maintainability" NAS in Ukraine.

\section{ORCID IDs}

Natalia Filonenko $D$ https://orcid.org/0000-0003-1219-348X, Alexander Babachenko@https://orcid.org/0000-0003-4710-0343, Ganna Kononenko@https://orcid.org/0000-0001-7446-4105

\section{REFERENCES}

[1] А.P. Huliaev, Металловедение [Metalsscience], (Moscow, Metallurgiya, 1986), p. 538. (in Russian)

[2] Jae Hoon Jang, In Gee Kimand H.K.D.H. Bhadeshia, Materials Science Forum, 638-642, 3319-3324 (2010), https://doi.org/10.4028/www.scientific.net/MSF.638-642.3319

[3] Bengt Hallstedt, Dejan Djurovic, Jörgvon Appen, Richard Dronskowski, Alexey Dick, Fritz Körmann, Tilmann Hickel and Jörg Neugebauer, CALPHAD: Computer Coupling of Phase Diagrams and Thermochemistry. 34(1), 129-133 (2010), https://doi.org/10.1016/j.calphad.2010.01.004.

[4] I.G. Wood, L. Vočadlo, K.S. Knight, D.P. Dobson, W.G. Marshall, G.D. Price and J. Brodholt, J. Appl. Cryst. 37, 82-90 (2004), https://doi.org/10.1107/S0021889803024695

[5] S.V. Tverdokhlebova, Visnyk Dnipropetrovskogo nacionalnogo universitetu. Serija Fizika. Radioelektronika, 14(12/1), 100-104 (2007). 
[6] O.V. Akymov and S.M. Nury, Eastern-European Journal of Enterprise Technologies, 6(11/78), 35-40 (2015).

[7] Moshe Ron, Hanan Shechter and S. Niedzwiedz, Journal of Applied Physics. 39265-39285 (1968).

[8] V.A. Kozheurov, Статистическая термодинамика [Statistical thermodynamics], (Moscow, Metallurgiya, 1975), p 75. (in Russian).

[9] O.Yu. Beryoza, N.Yu. Filonenko and O.S. Baskevich, Physics and Chemistry of Solid State. 13(3), 968-973 (2012).

\author{
ДОСЛІДЖЕННЯ РОЗЧИННОСТІ СИЛІЦЮ ТА МАНГАНУ В ЦЕМЕНТИТІ СПЛАВІВНА ОСНОВІ ЗАЛІЗА \\ Н.Ю. Філоненко ${ }^{1,2}$, О.І. Бабаченко ${ }^{2}$, Г.А. Кононенко ${ }^{2}$ \\ ${ }^{1}$ Д3 «Дніпропетровська державна медична академія МОЗ Украӥни» \\ 49044, Україна, м. Дніпро, вул. Володимира Вернадського, 9 \\ ${ }^{2}$ Інститут чорної металургї ім. 3. І. Некрасова НАН Украӥни (ІЧМ НАНУ) \\ 49107, Украӥна, м. Дніпро, пл. Ак. Стародубова К.Ф., 1
}

У роботі отримано вираз для вільної енергії цементиту та визначена розчинність мангану та силіцію в цементиті $\mathrm{Fe} 3 \mathrm{C}$ в залежності від температури. Дослідження проводили на сплавах з вмістом карбону 0,55-0,60 \% (мас.), силіцію 0,95-1,0 \% (мас.), мангану 0,8-0,9\% (мас.), решта - залізо. Виплавку сплавів системи $\mathrm{Fe}-\mathrm{Mn}-\mathrm{Si}-\mathrm{C}$ проводили в печі в алундових тиглях в атмосфері аргону. Швидкість охолодження виливки складала $10 \mathrm{~K} / \mathrm{c}$. Для визначення структурного стану сплавів використовували мікроструктурний та рентгеноструктурний аналізи. Окрім цього, в роботі були визначені механічні характеристики сплавів, що досліджували в даній роботі, а саме, залежність границі міцності, відносного видовження, відносного звуження, ударної в'язкості та твердості від хімічного складу сплаву. Отримані в даній роботі результати показали, що найкращі мікроструктурні та механічні характеристики має сплав на основі заліза 3 вмістом карбону 0,57 \% (мас.), силіцію $0,97 \%$ (мас.), мангану $0,85 \%$ (мас.). Основною структурною складовою всіх сплавів, які досліджували $\epsilon$ перліт (до 95 \% об'ємної частки). У сплавах були виявлені дрібнодисперсні включення карбідів $\mathrm{Fe}_{2,7} \mathrm{Mn}_{0,3} \mathrm{C}_{\text {та }} \mathrm{Fe}_{0,25} \mathrm{Mn}_{1,4} \mathrm{C}_{0,6}$ та $\mathrm{Fe}_{9} \mathrm{SiC}_{0,4}$, об'ємна частка яких склала до $1,5 \%$, інше - ферит. Цементит має великий вплив на фізико-механічні характеристики сплавів. За допомогою квазіхімічного методу була визначена вільна енергія цементиту, легованого манганом та силіцієм, а також була отримана залежність граничного вмісту кремнію і марганцю в цементиті в залежності від температури. Встановлено, що має місце підвищений вміст карбону в цементиті (до 28,79\% (ат.)). Манган може заміщати до $12 \%$ атомів заліза, а силіцій до $4,5 \%$ атомів заліза в залежності від температури. Отримані в роботі розрахункові дані добре узгоджуються з експериментальними даними інших авторів.

КЛЮЧОВІ СЛОВА: сплави системи $\mathrm{Fe}-\mathrm{Mn}-\mathrm{Si}-\mathrm{C}$, цементит, вільна енергія цементиту, розчинність мангану та силіцію в цементиті

\title{
ИССЛЕДОВАНИЕ РАСТВОРИМОСТИ КРЕМНИЯ И МАРГАНЦА В ЦЕМЕНТИТЕ СПЛАВОВ НА ОСНОВЕ ЖЕЛЕЗА \\ Н.Ю. Филоненко ${ }^{1,2}$, А.И. Бабаченко, А.А. Кононенко 2 \\ ${ }^{1}$ ГУ «Днепропетровская государственная медицинская академия МОЗ Украины»» 49044, Украина, г. Днепр, ул. Владимира Вернадского, 9 \\ ${ }^{2}$ Институт черной металлургии им. 3. И. Некрасова НАН Украины (ИЧМ НАНУ) 49107, Украина, г. Днепр, ул. Ак. Стародубова К.Ф., 1
}

В работе получено уравнение свободной энергии цементита и определена растворимость марганца и кремния в цементите $\mathrm{Fe}_{3} \mathrm{C}$ в зависимости от температуры. Исследования проводились на сплавах с содержанием углерода 0,55-0,60 \% (мас.), кремния 0,95-1,0 \% (мас.), марганца 0,8-0,9 \% (мас.), остальное - железо. Выплавку сплавов системы Fe-Mn-Si-C проводили в печи в алундових тиглях в атмосфере аргона. Скорость охлаждения отливки составляла 10 К/с. Для определения структурного состояния сплавов использовали микроструктурный и рентгеноструктурный анализы. Кроме этого, в работе были определены механические характеристики сплавов, а именно, зависимость предела прочности, относительного удлинения, относительного сужения, ударной вязкости и твердости от химического состава. Полученные результаты показали, что оптимальную микроструктуру и более высокие механические свойства имеет сплав на основе железа с содержанием углерода $0,57 \%$ (мас.), кремния $0,97 \%$ (мас.), марганца $0,85 \%$ (мас.). Основная структурная составляющая во всех исследованных сплавах - перлит (до 95 \% объёмной доли). В сплавах были обнаружены микродисперсные включения карбидов $\mathrm{Fe}_{2,7} \mathrm{Mn}_{0,3} \mathrm{C}$ та $\mathrm{Fe}_{0,25} \mathrm{Mn}_{1,4} \mathrm{C}_{0,6}$ та $\mathrm{Fe}_{9} \mathrm{SiC}_{0,4}$, объемная доля которых составила до 1,5\%, остальное - феррит. Как известно, структурной составляющей перлита является цементит. Цементит оказывает значительное влияние на физикомеханические свойства сталей. С помощью квазихимического метода была определена свободная энергия цементита, легированного кремнием и марганцем, а также была получена зависимость предельного содержания кремния и марганца в цементите в зависимости от температуры. Установлено, что имеет место повышенное содержания углерода в цементите (до $28,79 \%$ (ат.)). Марганец может замещать до $12 \%$ атомов железа, а кремний - до $4,5 \%$ атомов железа в зависимости от температуры. Полученные в работе расчетные данные хорошо согласуются с экспериментальными данными других авторов.

КЛЮЧЕВЫЕ СЛОВА: сплавы системы Fe-Mn-Si-C, цементит, свободная энергия цементита, растворимость марганца и кремния в цементите 